\title{
The Reflection and Outlook on the Study of Teachers' IT-Based Teaching Ability
}

\author{
Xiaojun Wei \\ School of Teacher Education, Sichuan University of Arts and Science, Dazhou, China \\ Email: scdzwxj@163.com
}

How to cite this paper: Wei, X.J. (2019) The Reflection and Outlook on the Study of Teachers' IT-Based Teaching Ability. Open Journal of Social Sciences, 7, 206-212. https://doi.org/10.4236/jss.2019.74017

Received: March 28, 2019

Accepted: April 14, 2019

Published: April 17, 2019

Copyright (C) 2019 by author(s) and Scientific Research Publishing Inc. This work is licensed under the Creative Commons Attribution International License (CC BY 4.0).

http://creativecommons.org/licenses/by/4.0/

\begin{abstract}
As a hot topic in the field of education, the study of teachers' IT-based teaching ability concerns various perspectives such as theoretical paradigm, practical approach, scholarship of teaching and so on. This paper analyzes the problems existing in the development of teachers' IT-based teaching ability. It is suggested that the improvement of IT-based teaching ability should be promoted from three aspects of school, teachers themselves and classroom teaching.
\end{abstract}

\section{Keywords}

IT-Based Teaching Ability, Various Perspectives, Teaching Scholarship, Transformation, Development Trend, Teaching Subject, Multiple Values

\section{Introduction}

The development of IT-based teaching in school, a vital base for knowledge spreading and talents cultivation, has a certain impact on the development process of educational informatization. IT-based teaching in school lies in teachers, whose ability to utilize information technologies in their teaching is not only the foundation of their professional development, but also the basis of cultivating innovative students. With constant attention paid by researchers and teachers to IT-based teaching ability, its application methods, effect and problems start to appear. Hence, it's necessary to analyze the process and trend of teachers' IT-based teaching ability development. This article aims at analyzing the plights of the development of teachers' IT-based teaching ability, according to which the trend of its studies is predicted.

\section{Various Perspectives of IT-Based Teaching Ability Study}

With the development of information technology, the ecological structure of 
school education has changed. Digitization and interactivity of teaching process are the most featured parts of IT-based teaching. Traditional class featuring verification can hardly meet the teaching demands in the information age. As network technology developing, students-centered learning model is establishing and teachers' role is changing. Information age calls for the transformation of teachers' teaching methods. Developing teachers' IT-based teaching ability means to reshape teachers' mission in class. More importantly, it means the reconstruction of teaching in the classroom. IT-based teaching ability study is based on teaching ability, which is explained by the author from different perspectives.

\subsection{From the Perspective of Theoretical Paradigm}

IT-based teaching ability is a new requirement for teachers' teaching ability in the information age, which is defined differently by researchers. In terms of theoretical paradigm, it can be divided into three dimensions: from the angle of teaching ability, the first dimension thinks that IT-based teaching ability is the extension of teaching ability; the second dimension equates IT-based teaching ability with IT application ability, considering that it is a simple combination of teaching and tools; the third dimension argues that IT-based teaching ability is an academic activity from the perspective of its connotation and structure. The diverse studies on IT-based teaching ability show a creative feature of teaching ability in the information age. Generally, it is considered that IT-based teaching ability combines multiple abilities, thus it should be analyzed from different aspects [1].

\subsection{From the Perspective of Teaching Practice}

Teachers' important role of spreading knowledge and developing academics makes their IT-based teaching ability the significant foundation of teaching and scientific research. Traditional teaching models emphasize imparting knowledge. As a result, knowledge is passed on and continued. However, new requirement for innovative talents cultivation is raised by the information age, which is a transformation from knowledge inheritance to knowledge creation. Information technology has a so strong impact on education that it has concerned the existence value of education. With the application of information technologies such as MOOCs, SPOCs, Flipped Classroom and education cloud platforms, teachers' living space has been continuously pressured and they have been at loss when dealing with the shock of educational informatization. It has attracted wide attention among researchers about how to balance scientific research, teaching and information technology. The transformation of teaching methods is not a negation of the traditional ones, but an attempt to change teaching and learning methods according to the requirements of the information age and curriculum characteristics. At present, the practice of teachers' IT-based teaching ability still remains in theoretical illustration. The model of IT-based teaching practice is 
not mature enough and lacks adequate verification. The specific methods, model, evaluation and effect of IT-based teaching practice are still under research [2].

\subsection{From the Perspective of Teaching Scholarship}

With the development of educational informatization, teachers' IT-based teaching ability level has become a crucial factor in their professional development. Early in 1990, Ernest L. Boyer, chairman of Carnegie Foundation for the Advancement of Teaching, put forward the idea of "scholarship of teaching", which reestablished the position of teaching in school. According to his theory, teachers' teaching is considered as a scholarship activity, thus it should be studied academically. In the information society, the scholarship of teaching directly embodies in teachers' IT-based teaching ability. It is a demand of the time made by the information society to teachers' teaching ability. Under the background of educational informatization, school education is facing the diversified development of teaching environment, resources and methods. Teachers' IT-based teaching ability needs to adapt to this change. Just like Ernest L. Boyer's division of scholarship into scholarship of discovery, scholarship of integration, scholarship of application and scholarship of teaching [3], teachers' IT-based teaching ability should also be divided into media utilization ability, teaching design ability and subject integration ability. This ability should allow teachers to change from ideological concept, put teaching design into practice, and integrate information technology with curriculum in specific subjects. Bearing in mind the concept of IT-based teaching, teachers should actively adapt to the teaching environment, improve their ability to design IT-based teaching, and integrate information technology with different subjects, thus improving the quality of education and teaching.

\section{The Transformation of Teachers' Teaching Ability in the Information Society: Driven by Predicament}

\subsection{Weak Identification with IT-Based Teaching Concepts: Challenge for Teachers' Professional Survival}

As information technology developing rapidly, it has caused great changes in different fields of the society, including in education. With the application of MOOCs, SPOCs, Flipped Classroom, education cloud platforms and other technologies, online education platforms have threatened the existence of schools, and some people even put forward the "death of schools" theory. In this context, in face of IT-based teaching, some teachers still have thoughts like "afraid to use, unable to use, and unwilling to use". The reason why they are afraid to use is that in the information age, knowledge is accessible to everyone. Knowledge on information platforms can be richer and more interactive than teachers' teaching. Excessive reliance on information platforms can weaken teachers' teaching ability. Some teachers are unwilling to use because teachers from different disciplines, their level of utilizing informatization is different as 
well. some of them consider IT-based teaching methods trival, even causing informatization anxiety. While some exclude information technology, holding the idea of "omnipotent blackboard", thus underestimating the effect of information technology. The reason why some teachers are unable to use is because though most of them apply computer-aidded teaching in class, the effect is not ideal. There is a digital gap between teachers and students. Some teachers equate the digitalization of teaching process with educational informatization. Teachers' weak identification with the concept of IT-based teaching is an obstacle to the development of IT-based teaching ability and a challenge for the survival of teachers. Only by changing their mind, recognizing and using IT-based teaching methods can educational informatization become possible and adapt to the ability requirements of informatization for teachers [4].

\subsection{Inadequate Teaching Design Ability: The Need to Improve Teaching Ability}

As a bilateral activity between teachers and students who make use of educational media and information resources, IT-based teaching has no difference with traditional teaching in essence. Its advantage lies in IT-based teaching methods, which mean the application of new technologies and media in the teaching process. IT-based teaching design is incomplete. What's worse, some teachers simply equate multimedia teaching with IT-based teaching. Information technology is separated from teaching in the design process. People utilize informatization for the sake of informatization without truly integrating curriculum content with IT-based teaching methods. In addition, some teachers pursue new technologies blindly, thinking that teaching results depend on the level of new technologies. Hence, they put more emphasis on the development of platforms and software than the innovation and application of teaching concepts, thus causing their lost in themselves and teaching, and IT-based methods override teachers [5].

\subsection{Inadequate Subject Integration Ability: Integration with Teachers' Professional Curriculum}

Different subjects and fields make the connotation of IT-based teaching different. However, it's necessary for teachers to combine information technology with professional curriculum, so that students can be introduced into professional academic fields and make achievements in their professional development. The inadequacy of subject integration ability embodies in informatization training and application. Teachers' training programs organized by schools have little content concerning IT-based teaching, some of which often just stay on the level of specific tools or simple usage of information technology. They put one-sided emphasis on the application of technical tools and ignore the different usage in specific subjects. When utilizing information technologies in subjects, teachers, constrained by the ability to use information technologies, often just present the teaching content in digital forms without completing its informatiza- 
tion process. Some teachers are not capable of searching and sorting out subject resources, finding out and putting forward teaching questions, and transferring and utilizing on the basis of platform [6].

\subsection{Insufficient Recognition of IT-Based Teaching Subject: Misunderstanding of Teaching Subject}

The ultimate goal of education is the all-round development of student's comprehensive qualities. In this information society, teachers' mission is to meet the demands of the information age so as to facilitate students' all-round development. In IT-based teaching, the development of subject should refer to that of both teachers and students. Subjectivity can be developed through interactions between students, between teachers and students, and between people and information technology, which is an important characteristic of IT-based teaching. Teachers' subjectivity can't be developed properly provided that teachers spend a lot of time digitizing information and networking resources in order to utilize informatization methods. Similarly, students' subjectivity can't be developed either simply by means of people-information technology interactive method in IT-based teaching environment. If the transformation from teacher-oriented class to information-oriented class can't promote the development of teachers' and students' subjectivity, problems such as uncertainty of teaching information and teaching disorder may appear. Therefore, teachers need to adapt to the demands of the information age to teaching subject. In face of the brand new way of information spreading and open learning culture, teachers should change their role, and narrow the digital gap with students through IT-based teaching, thus realizing the synchronous development of teachers and students.

\section{The Development Trend of Teachers' IT-Based Teaching Ability}

\subsection{School: From Vocational Training Support to Resources Optimization and Integration}

The development of teachers' IT-based teaching ability is a systematic and continuous process. At present, the pre-service training and on-the-job training of teachers are important links to improve teachers' IT-based teaching ability. The construction of digital campus has begun to take shape, but the effect of teachers' IT-based teaching seems unsatisfactory. The reason is that some training programs pay no attention to the characteristics of different majors, and fail to combine information technology with professional content, so they can't achieve good teaching effect. To enhance teachers' IT-based teaching ability, on the one hand, teachers should use information technology means to learn autonomously in their lifetime. In addition, they should, through information technology methods, improve their information literacy, adapt to the requirements for teachers in the educational information age, stand firm and behave well on the platform, and restore the authority and value of teachers with the help of informatization 
ability. In this sense, teachers should bear in mind the concept of IT-based teaching. In the information society, teachers' IT-based teaching and learning is a process of continuous self-improvement, professional development and a drive for self-growth. Only when teachers consciously set up the academic concept of IT-based teaching and put it into practice can they improve the level of IT-based teaching fundamentally. Schools should set up and improve teaching resources database, online education platforms, conduct overall planning of information resources, and improve the utilization of teaching resources. On the one hand, information resources should be used in the teaching process. Meanwhile, teachers should collaborate with teachers from other schools by online education platforms, thus expanding knowledge scope, and improving their knowledge and skills, so as to promote the all-round development of students.

\subsection{Teacher: From Design Model Research to Design Results}

IT-based teaching is the process in which teachers apply information technologies to disseminate knowledge, which reflects teachers' design ability as well as the analysis ability of course content theory and practice. During this process, means and tools are not the standards for teaching ability. American communication scientist Wilbur Schramm puts forward that there are no omnipotent media, and thinks that the coordination of media and teaching order is of particular importance. Therefore, as for IT-based teaching design, teachers should always perform teaching reflection by combining teaching practice. Meanwhile, they should also focus on students by making full use of various information technologies to serve teaching and help students study. Teachers should start from question-oriented design to inspire students' initiative, and make full use of information resources to solve various problems in the teaching process. IT-based teaching designer should study design theories and pay attention to design results as well. In IT-based teaching process, more design examples and works need to be shown to students. The process of teachers' IT-based teaching design is by no means the practice of information technology. Teachers should constantly integrate information technology into teaching and repeatedly think and explore, so as to improve IT-based teaching design ability. Teachers' application of information technology should become a kind of technical self-consciousness and a continuous and life-long teaching practice process.

\subsection{Classroom: From Media Tools Orientation to Multiple Values Orientation}

Classroom is a vital place to lead students into professional fields. The research on teachers' IT-based teaching ability is the research on their teaching ability in the classroom, rather than being separated from the existing environment. Instead of staying at the stage of using media tools and discussing how to apply new technology to teaching environment, the research on IT-based teaching ability must be carried out in a certain cultural environment from multiple an- 
gles and perspectives. In order to realize the transformation of information technology from serving teachers to serving students, the research on IT-based teaching ability should pay attention to the realization of teachers' and students' value. The improvement of teachers' IT-based teaching ability affects the level of students' professional development and meets the needs of students' all-round development. Teaching is a teacher-student bilateral activity that teachers combine information means, tools and resources with professional disciplines, and classroom is a place for teachers and students to exchange knowledge and realize value. Teachers should study subject content in depth, actively use information means, and integrate it with subject content, so as to truly adapt to the new requirements of the times for teachers, thus making technology in classroom teaching full of vitality.

\section{Conflicts of Interest}

The author declares no conflicts of interest regarding the publication of this paper.

\section{References}

[1] Liu, Z. and Yin, R. (2014) Connotation and Improvement Path of Teachers' IT-Based Teaching Ability. Journal of the Chinese Society of Education, No. 10, 31-36.

[2] Hu, X.L. (2012) Structure Analysis of IT-Based Teaching Ability of University Teachers. Modern Distance Education, No. 6, 67-72.

[3] Boyer, E. (1997) Scholarship Reconsidered: Priorities of the Professorate. Josie-Bass, San Francisco.

[4] Li, T.L. (2011) Exploration and Analysis of Ways to Develop Young Teachers' IT-Based Teaching Ability. E-Education Research, No. 12, 106-120.

[5] Wang, W.J. (2012) IT-Based Teaching Ability: Teachers Challenging Information Society. Modern Distance Education, No. 2, 45-53.

[6] Kang, S.M. (2015) Research on the Reform of Teaching Methods in the Context of Informatization. Educational Research, No. 6, 96-102. 